Article

\title{
The Causal Connection of Natural Resources and Globalization with Energy Consumption in Top Asian Countries: Evidence from a Nonparametric Causality-in-Quantile Approach
}

\author{
Hafezali Iqbal Hussain ${ }^{1,2}$, Muhammad Haseeb ${ }^{1}$ (D), Manuela Tvaronavičienè ${ }^{3,4, * \mathbb{D}}$, \\ Leonardus W. W. Mihardjo ${ }^{5}$ and Kittisak Jermsittiparsert 6,7 \\ 1 Taylor's Business School, Taylor's University, 1 Jalan Taylors, Subang Jaya 47500, Selangor, Malaysia; \\ hafezali.iqbalhussain@taylors.edu.my (H.I.H.); muhammad.haseeb@taylors.edu.my (M.H.) \\ 2 University of Economics and Human Sciences in Warsaw, Okopowa 59, 01-043 Warsaw, Poland \\ 3 Vilnius Gediminas Technical University, Sauletekio 11, 10223 Vilnius, Lithuania \\ 4 General Jonas Zemaitis Military Academy of Lithuania, Silo 5a, 10322 Vilnius, Lithuania \\ 5 Bina Nusantara University, 11530 Jakarta, Indonesia; mihardjo@gmail.com \\ 6 Department for Management of Science and Technology Development, Ton Duc Thang University, \\ Ho Chi Minh City 758307, Vietnam; kittisak.jermsittiparsert@tdtu.edu.vn \\ 7 Social Research Institute, Chulalongkorn University, Bangkok 10330, Thailand \\ * Correspondence: manuela.tvaronaviciene@vgtu.lt
}

Received: 29 March 2020; Accepted: 19 April 2020; Published: 5 May 2020

\begin{abstract}
Given the significance of energy conservation as a prime objective of environmental sustainability, countries all around the world are keen to identify significant factors that lead to the augmentation of energy utilization. Considering the rising emphasis of economies in utilizing natural resources to attain higher levels of globalization, the current research was aimed at investigating how the returns of natural resources and globalization affect energy consumption in top Asian economies. In doing so, the study emphasized the nonlinear relationship among the variables and applied the novel nonparametric method of causality in quantile to identify the quantile-based causal connection of natural resources and globalization on the returns and volatility of energy utilization in selected Asian countries. Moreover, the presence of nonlinearity in the variables was tested by the BrockDechert-Scheinkman test (BDS test), which confirmed that all variables showed nonlinear behavior. Furthermore, the findings of quantile cointegration confirmed a nonlinear long-run relationship of natural resources and globalization with energy utilization. The prime findings of causality in quantile revealed that the returns of natural resources and globalization had a significant causal effect on the returns of energy consumption in all countries. On the other hand, the volatility in energy consumption concluded no causal association with the returns of natural resources and globalization in any of the studied Asian countries. The findings are beneficial for the policymakers to formulate policies that will help to reduce the level of energy consumption.
\end{abstract}

Keywords: natural resources; globalization; energy; nonparametric causality in quantiles

\section{Introduction}

Natural resources are the resources that are bestowed on a country by nature, without any particular investment by the country, and they are considered one of the most influential determinants of the economic development of a country [1-5].

Therefore, most of the investments of resource-abundant countries are normally focused on extraction, which itself is a huge and critical area for natural scientists, environmental economists, 
and practitioners [6]. Resource-abundant countries fall into two categories: (1) Richly endowed, where countries transform their operations for the advancement of the capacity and capability of various industries and direct the extraction of the natural resources towards the betterment of the economic development and financial health of the country [7]. (2) Narrowly focused, where countries make themselves and their respective economies more dependent on the natural resources by focusing most of the industries in the same field thus increasing the level of dependency on the presence of the natural resources [8-10].

Natural resources enable direct foreign investment to a country, and that has a tendency to improve the standard of living of the locals [11,12], however, it also adversely affects the potential growth of the country in the long term [13], thus making the host country intensely dependent on the consumption and extraction of the natural resources; this is referred to as a resource curse [14-18].

Moreover, most researchers are in agreement with respect to the adverse association between economic development and natural resources of a country [19-21]. Researchers also suggest that by improving institutional quality, having a good incentive program to the personnel engaged in the respective activities [22], and strengthening the political stability [23], the country can counter the phenomenon of being trapping in a resource curse.

Globalization refers to the phenomenon where countries are consolidated by means of intercountry and direct investments, which make the countries grow together by nurturing their potential and capabilities and fostering economic development [24].

Conventionally, the term was used for the development of communication and transportation infrastructure that creates connectivity among the countries, however, the scope of the term has broadened [2]. By strengthening foreign trade among countries, globalization can enhance the capabilities, capacity, and efficiency of the manufacturing countries and contribute significantly to achieving economies of scales [24-26]. Moreover, availability of abundant natural resources also leads to an increase in globalization, because the countries that have resources can transform them into a usable form that can be exported to the counties lacking those resources [27]. Therefore, natural resources also increase foreign trade, foreign investments, and foreign exchange, which increase globalization and improve the efficiency of energy consumption [2,28].

Despite of the generation of value-added services and goods by the consumption of energy, energy consumption damages the environment and adversely contributes to global climate change [29]. For instance, oil- and gas-oriented companies while transforming the natural resources into usable forms consume most of the energy, and hence pollute the environment [30,31]. Moreover, natural resources extraction leading to an increased energy consumption can ultimately harm the global environment. Therefore, protecting and safe guarding the environment is of significant importance [32-35].

Asian countries, on one hand, are progressive and fast growing regions in terms of industrialization, urbanization, globalization, and population. On the other hand, they significantly contribute adversely to global pollution, climate change, and environment degradation [36,37].

Despite Asian countries being a major contributor to pollution and climate change, the current literature mainly focuses on the regions of the Organisation for Economic Co-operation and Development (OECD) countries and Asian countries have received less focus [38,39]. Therefore, this led to the motivation of the present study to examine the dynamic effects of natural resources and globalization on energy consumption in top Asian countries.

The remainder of this paper is arranged as follows: The next section presents evidence from the literature, followed by a discussion of the methodology of the present study. Next, estimations and findings of the study are discussed. Finally, conclusions are drawn and recommendations are given to the practitioners and policy makers for future guidance in devising strategies based on the findings of the present study. 


\section{Literature Review}

The theoretical connection of globalization asserts that as the economy is globalized, its level of energy utilization changes. Being the prime source of energy, nearly $65 \%$ of worldwide carbon emanations come from the burning of fossil-fuels [40]. Following the apparent link, many studies believe that globalization is a crucial aspect of motivating energy usage. However, the rise or decline in the levels of energy depend on the net effect of multiple factors within the globalization. Generally, the upsurge in global output and income levels are linked with enhanced consumption and manufacturing along with the elimination of trade barricades due to enhanced globalization. This in turn amplifies energy usage and leads to a positive association [41]. On the other hand, the negative link between globalization and energy usage can also be attributed to new ventures leading to innovation spillover, which can assist in reducing energy usage by supporting energy efficient research [42]. Hence, the energy efficiency derived from importing skills as a result of globalization can reduce power usage, however, a rise in efficiency can only offset a portion and not all of the energy needs of an economy.

Similarly, the theoretical link between globalization and energy usage is also supported by the popular scale effect, technique effect, and composition effect [42]. The assumption of the scale effect asserts the positive connection between globalization and energy by stating that the expansion of fresh industries and economic activities augments energy usage [43,44]. Moreover, the alternative presumption of technique effect proclaims that a rise in globalization often empowers the economies to lower their energy utilization through importing progressive technologies and inflows of capital and supports the negative connection among the variables without obstructing the economic structure [45]. Finally, the composition effect in globalization confers the changes in energy intensity to the alteration in a country's industrial structure [46]. For instance, the emergence of globalization empowers a production shift from agriculture to industry and ultimately to the service industry, and thus changes the economic composition towards the sectors that demand lower energy use [40].

By linking higher levels of consumption and production to the environment, it is believed that the demand shift results in more eco-intensive processing that enlarges the environmental burden by putting more pressure on energy-insensitive processes [47]; this hinders the country's prospects of sustainable development. Conventionally, the dependence on natural resource consumption has been argued to persist the resource curse as it hinders sustainability of the economy by hindering growth [48]. In this regard, it is believed that countries having sufficient natural resources experience diminutive growth relative to those of resource-scarce economies [49]. Alternatively, many recent studies contradicted the concepts of a resource curse and found natural resources to be a blessing for countries [50]. Moreover, the growing dependence of economies on the utilization of natural resources demands reliable and sustainable access to numerous natural resources, such as forestry, water, minerals, productive land, and essential metals [51]. However, given the rate at which resource depletion is occurring, the physical accessibility of such natural resources is considered challenging. The dependence of many economies on minerals and metal extraction by consuming excessive amount of energy leads to environmental destruction [52]. In response, green sources of energy have provided a fine solution to fulfil energy needs with minimal pressure on the environment, but the installation and completion of green projects are often fossil-based and energy-dependent [53], while certain green sources such as biomass, wood, waste, and plants also enhance the pressure on natural resources and their sustainable access [54]. Hence, based on the above reasons, the link of globalization and natural resources with energy consumption is considered rather complex and needs to be re-evaluated in different time-series settings with the utilization of advanced methods to ensure the reliability of the derived findings [51].

\section{Empirical Studies}

Numerous research studies in the prevailing literature evaluated factors that contribute to environmental destruction [55]. Among them, energy consumption is regarded as a vital stimulator of environmental pollution [56]. The role of energy is inevitable for growth, however, by acknowledging 
the damaging consequences of energy use in climate change, the current economies are motivated to recognize the in-depth aspects of energy dependence so as to combat the environmental impact of energy use in the process of atmospheric downfall [57]. Following the adverse impact of energy dependence on environmental quality [58], particularly in damaging the ozone layer and emitting greenhouse gases [59], many studies have sought to identify the antecedents of energy usage in both developed $[60,61]$ and developing economies $[62,63]$.

For instance, Shahbaz et al. [40] examined the causal effect between globalization on energy utilization in twenty-five advanced countries. For this, the authors utilized the data from the timespan of 1970-2014. The empirical results of the study found significant causal associations among the variables in 14 out of 25 economies. Specifically, the results demonstrated the positive causal link between globalization and energy utilization in the majority of the studied economies except for in the UK and USA, where the rise in globalization was found to decrease energy usage. Lastly, the study reported that in the economies of Italy, New Zealand, Finland, Greece, Ireland, Portugal, Austria, Spain, Iceland, and Denmark, globalization did not exert significant influence on energy utilization. Also, Shahbaz et al. [41] examined the link between globalization and energy utilization in the economies of Ireland and the Netherlands. For this, the authors utilized the time-series quarterly data from the timespan of 1970-2015. The empirical results of the study found a significant impact of globalization on energy usage in the long run. Interestingly, the results stressed that a rise in globalization carried an upsurge in energy utilization in both of the highly globalized economies that were studied. However, the results failed to validate the existence of a short-term link among the considered variables.

Furthermore, in India, Shahbaz, Mallick, Mahalik, and Sadorsky [42] investigated the connection of globalization with energy utilization. For this, the authors utilized the time-series data from the timespan of 1971-2012 by applying the Autoregressive-Distributed Lag (ARDL) approach to perform empirical examination. The empirical outcomes of the study confirmed the presence of a significant link between globalization and energy utilization. Moreover, the results stressed that an increase in globalization curtails the adversities to the environment by lowering the level of energy usage in the Indian economy. For the economies of Indonesia, Malaysia, and Thailand, Azam et al. [63] analyzed the factors affecting energy utilization. For this, the authors utilized the time-series data from the timespan of 1980-2012. The empirical results of the study found a significant impact of globalization in the form of trade liberalization and foreign direct investment (FDI) in enhancing energy usage in the considered economies by documenting the presence of positive relationships among the variables.

In Bangladesh, Murshed, Tul-Jannat, and Amin [64] analyzed the impact of globalization on energy utilization in Pakistan. For this, the authors utilized the time-series data from the timespan of 1980-2015. The empirical results of the study stated that globalization had no causal relationship with energy usage in Bangladesh. Utilizing the indicator of trade openness to measure globalization, Shahbaz, Loganathan, Sbia, and Afza [65] also examined the link between globalization and energy utilization in Malaysia between 1970 and 2011. Similar to the findings of Azam et al. [63], the empirical results of the study also confirmed the positive influence of trade openness on energy usage in Malaysia. Bringing the impact of renewable energy to the globalization-energy nexus, Koengkan, Poveda, and Fuinhas [66] recently analyzed the impact of globalization on renewable energy utilization in Latin America. For this, the authors utilized the panel data for ten Latin American economies from 1980 to 2014. The empirical results of the study found a significant impact of globalization on renewable energy usage, highlighting that the rise in globalization led to an augmentation of the utilization of renewable energy in the studied economies.

Shahbaz et al. [67] investigated the relationship between globalization and energy utilization by validating the possibility of an environmental Kuznets link. For this, the authors utilized the mix panel data of eighty-six economies from the timespan of 1970-2015. The empirical results of the study validated the environmental Kuznets curve (EKC) hypothesis in a majority of the studied economies. Specifically, the results found that in sixty-four economies, the rise in globalization enhanced energy usage initially but ultimately resulted in increased energy efficiency and decreased energy consumption. 
In another panel estimation, Rahman and Miah [27] examined the influence of numerous sources of energy on the level of globalization in a panel of twenty-six economies between 1990 and 2010 . The findings documented that utilization of nonrenewable sources for power generation resulted in decreasing globalization in the studied economies. Alternatively, the adoption of green sources of energy were found to exert a positive influence on globalization in the considered sample.

Identifying the causal connection between green energy, fossil-based energy, and natural resources, Bekun, Alola, and Sarkodie [68] analyzed the panel of sixteen European economies. For this, the authors utilized the panel data from the timespan of 1996-2014. The empirical results of the study found that natural resources exert a unidirectional causal effect on both renewable and nonrenewable energy consumption. In Ghana, Kwakwa, Alhassan, and Adu [33] examined the link between the extraction of natural resources and energy utilization and carbon emanation. For this, the authors utilized the time-series data from the timespan of 1971-2013. The empirical results of the study found a significant impact of natural resources on energy as well as carbon discharge in Ghana. Specifically, the results reported that a rise in the extraction of natural resources enhanced the energy utilization and environmental degradation in the country.

\section{Methodology}

In the present study, an innovative hybrid approach for the identification of nonlinear based causality was employed, which was discussed and proposed by Balcilar et al. [1] and was founded on the frameworks proposed by Jeong et al. [69] and Nishiyama et al. [70]. The energy consumption is denoted by $\mathrm{y}_{\mathrm{t}}$ and natural resources and globalization are denoted by $x_{1 t}$ and $x_{2 t}$, respectively. As discussed by Jeong et al. [69] in the $\theta$-th quantile, $y_{t}$, will not be effected by $x_{1 t}$ and $x_{2 t}$, respectively, in terms of lag vector $\left\{y_{t-1}, \ldots, y_{t-p}, x_{1 t-1}, \ldots, x_{1 t-p}, x_{2 t-1}, \ldots, x_{2 t-p}\right\}$, whereby:

$$
Q_{\theta}\left(y_{t} y_{t-1}, \ldots, y_{t-p}, x_{1 t-1}, \ldots, x_{1 t-p}, x_{2 t-1}, \ldots, x_{2 t-p}\right)=Q_{\theta}\left(y_{t} y_{t-1}, \ldots, y_{t-p}\right)
$$

Moreover, the prima facie effect by $x_{1 t}$ and $x_{2 t}$, respectively, on $\mathrm{y}_{\mathrm{t}}$ in the $\theta$-th quantile in terms of $\left\{y_{t-1}, \ldots, y_{t-p}, x_{1 t-1}, \ldots, x_{1 t-p}, x_{2 t-1}, \ldots, x_{2 t-p}\right\}$ is:

$$
Q_{\theta}\left(y_{t} y_{t-1}, \ldots, y_{t-p}, x_{1 t-1}, \ldots, x_{1 t-p}, x_{2 t-1}, \ldots, x_{2 t-p}\right) \neq Q_{\theta}\left(y_{t} y_{t-1}, \ldots, y_{t-p}\right)
$$

where $Q_{\theta}\left(y_{t} \bullet\right)$ represents the $\theta$-th quantile of the $y_{t}$ subject to $t$ and $0<\theta<1$. Moreover, the conditional distribution function of $y_{t}$ is denoted by $Y_{t-1} \equiv\left(y_{t-1}, \ldots, y_{t-p}\right), X_{1 t-1} \equiv\left(x_{1 t-1}, \ldots, x_{1 t-p}\right), X_{2 t-1} \equiv$ $\left(x_{2 t-1}, \ldots, x_{2 t-p}\right), Z_{t}=\left(X_{1 t}, X_{2 t}, Y_{t}\right), F_{y_{t} \mid} Z_{t-1}\left(y_{t} \mid Z_{t-1}\right)$, and $F_{y_{t} \mid} \mid Y_{t-1}\left(y_{t} \mid Y_{t-1}\right)$, where $Z_{t-1}$ and $Y_{t-1}$ are given, respectively. It is supposed that the conditional distribution $F_{y_{t} \mid Z_{t-1}}\left(y_{t} \mid Z_{t-1}\right)$ is absolutely continuous in terms of $y_{t}$ for all $Z_{t-1}$. Furthermore if it is represented that $Q_{\theta}\left(Z_{t-1}\right) \equiv Q_{\theta}\left(y_{t} \mid Z_{t-1}\right)$ and $Q_{\theta}\left(Y_{t-1}\right) \equiv Q_{\theta}\left(y_{t} \mid Y_{t-1}\right)$ will have $F_{y_{t} \mid Z_{t-1}}\left\{Q_{\theta}\left(Z_{t-1}\right) \mid Z_{t-1}\right\}=\theta$ with a probability of 1 . Therefore, as per the Equations (1) and (2), the hypotheses that need to be tested are shown below:

$$
\begin{aligned}
& H_{0}: P\left\{F_{y_{t} \mid Z_{t-1}}\left\{Q_{\theta}\left(Y_{t-1}\right) \mid Z_{t-1}\right\}=\theta\right\}=1 \\
& H_{1}: P\left\{F_{y_{t} \mid Z_{t-1}}\left\{Q_{\theta}\left(Y_{t-1}\right) \mid Z_{t-1}\right\}=\theta\right\}<1
\end{aligned}
$$

As per the framework proposed by Jeong et al. [69], the measure is used to compute the distance, which is $J=\left\{\varepsilon_{t} E\left(\varepsilon_{t} \mid Z_{t-1}\right) f_{Z}\left(Z_{t-1}\right)\right\}$, whereas the regression error is represented by $\varepsilon_{t}$ and the function of marginal density of $Z_{t-1}$ is represented by $f_{Z}\left(Z_{t-1}\right)$. The regression error is calculated when the null hypothesis is found true as presented in Equation (3), which is possible only in the scenario where 
$E\left[1\left\{y_{t} \leq Q_{\theta}\left(Y_{t-1}\right) Z_{t-1}\right\}\right]=\theta$ or equivalently $1\left\{y_{t} \leq Q_{\theta}\left(Y_{t-1}\right)\right\}=\theta+\varepsilon_{t}$, whereas the indicator function is represented by $1\{\bullet\}$. The distance function as specified by Jeong et al. [69] is shown below:

$$
J=E\left[\left\{F_{y_{t} \mid Z_{t-1}}\left\{Q_{\theta}\left(Y_{t-1}\right) \mid Z_{t-1}\right\}-\theta\right\}^{2} f_{Z}\left(Z_{t-1}\right)\right]
$$

As shown in Equation (3), it is imperative to consider that $J \geq 0$; only when $\mathrm{H}_{0}$, as shown in Equation (5), becomes true will $J=0$, whereas as shown in Equation (4), the values $J>0$ are underneath the alternative hypothesis that is $H_{1}$. Moreover, the feasible test statistic based on the kernel function as discussed by Jeong et al. [69] for J can be shown as follows:

$$
\hat{J}_{T}=\frac{1}{T(T-1) h^{2 p}} \sum_{t=p+1}^{T} \sum_{s=p+1, s \neq t}^{T} K\left(\frac{Z_{t-1}-Z_{s-1}}{h}\right) \hat{\varepsilon}_{t} \hat{\varepsilon}_{s}
$$

In Equation (6), the kernel function is represented by $K(\bullet)$, having bandwidth $h$, sample size is represented by $T$, lag-order is shown by $\mathrm{p}$, the estimated unknown regression error is calculated by $\hat{\varepsilon}_{t}$, which is computed as:

$$
\hat{\varepsilon}_{t}=1\left\{y_{t} \leq \hat{Q}_{\theta}\left(Y_{t-1}\right)\right\}-\theta
$$

In Equation (7), the $\theta$-th quantile of $y_{t}$ is calculated by $\hat{Q}_{\theta}\left(Y_{t-1}\right)$, whereby $\left(Y_{t-1}\right)$ is given. Moreover, $\hat{Q}_{\theta}\left(Y_{t-1}\right)$ can be calculated through the kernel method, which is based on a nonparametric method and is shown below:

$$
\hat{Q}_{\theta}\left(Y_{t-1}\right)=\hat{F}_{y t \mid Y_{t-1}}^{-1}\left(\theta Y_{t-1}\right)
$$

where the estimator of the Nadarya-Watson kernel is represented by $\hat{F}_{y t \mid Y_{t-1}}\left(y_{t} Y_{t-1}\right)$ and is given as:

$$
\hat{F}_{y t \mid Y_{t-1}}\left(y_{t} Y_{t-1}\right)=\frac{\sum_{s=p+1, s \neq t}^{T} L\left(\frac{Y_{t-1}-Y_{s-1}}{h}\right) 1\left(y_{s} \leq y_{t}\right)}{\sum_{s=p+1, s \neq t}^{T} L\left(\frac{Y_{t-1}-Y_{s-1}}{h}\right)}
$$

In Equation (9), the kernel function is represented by $L(\bullet)$ and the bandwidth is represented by $h$.

While extending the framework proposed by Jeong et al. [69], a test was developed for the 2nd moment. For this purpose, the nonparametric approach, which is quantile causality based on Granger as suggested and proposed by Nishiyama et al. [70], was used. While computing the higher-order moment, the illustration of causality is assumed as:

$$
y_{t}=g\left(Y_{t-1}\right)+\sigma\left(X_{1 t-1}\right) \varepsilon_{t}+\sigma\left(X_{2 t-1}\right) \varepsilon_{t}
$$

where the noise process is represented by $\varepsilon_{t}$, and stationery conditions are satisfied through unknown functions, which are $g(\bullet)$ and $\sigma(\bullet)$. Moreover, it should be noted that the aforementioned description is not in accordance with the testing of Granger type causality from $x_{1 t}$ and $x_{2 t}$ to $y_{t}$, respectively, however, it has the possibility for detection of nonlinear predictive power, which is computed from $x_{1 t}$ and $x_{2 t}$ to $y_{t}{ }^{2}$ whereas $\sigma(\bullet)$ is the function of general nonlinearity. Therefore, for explaining the variation through Granger causality, the explicit description of squares of $X_{1 t-1}$ and $X_{2 t-1}$ are not required. Moreover, the hypotheses forms of Equation (10) for the purpose of explanation of variation are shown below:

$$
\begin{aligned}
& H_{0}: P\left\{F_{y_{t}^{2} \mid Z_{t-1}}\left\{Q_{\theta}\left(Y_{t-1}\right) \mid Z_{t-1}\right\}=\theta\right\}=1 \\
& H_{1}: P\left\{F_{y_{t}^{2} \mid Z_{t-1}}\left\{Q_{\theta}\left(Y_{t-1}\right) \mid Z_{t-1}\right\}=\theta\right\}<1
\end{aligned}
$$

In order to test the null hypothesis as shown in Equation (11), a feasible test statistic was obtained and $y_{t}$ was replaced in Equations (6)-(9), with $y_{t}{ }^{2}$. Moreover, the issue related to the causality was resolved by incorporating the methodology proposed by Jeong et al. [69], in which conditional causality 
in the 1st moment (mean) denotes causality in the 2nd moment (variance). Therefore, in order to resolve this concern, the causality in the scenario of the higher order moments was examined and evaluated by utilizing the model as shown below:

$$
y_{t}=g\left(X_{1 t-1}, X_{2 t-1}, Y_{t-1}\right)+\varepsilon_{t}
$$

Therefore, the quantile causality based on higher order is stated as:

$$
\begin{gathered}
H_{0}: P\left\{F_{y_{t}^{k} \mid Z_{t-1}}\left\{Q_{\theta}\left(Y_{t-1}\right) \mid Z_{t-1}\right\}=\theta\right\}=1 \text { for } k=1,2, \ldots, K \\
H_{1}: P\left\{F_{y_{t}^{k} \mid Z_{t-1}}\left\{Q_{\theta}\left(Y_{t-1}\right) \mid Z_{t-1}\right\}=\theta\right\}<1 \text { for } k=1,2, \ldots, K
\end{gathered}
$$

By integration of the whole framework, $y_{t}$ is caused by $x_{1 t}$ and $x_{2 t}$ Granger in the quantile $\theta$ up to the Kth moment by employing Equation (14), whereby for each k, the test static using Equation (6) is constructed. Moreover, since the statistics are correlated mutually, for the combined null hypothesis shown in Equation (14), it is extremely difficult to join the diverse statistics for each $k=1,2,3 \ldots$ $K$ [70]. Therefore, as per the recommendations proposed by Nishiyama et al. [70], this issue was efficiently addressed by including a modified method based on sequential testing. At the first stage, the nonparametric Granger causality in the 1 st moment is $k=1$. When rejecting of null hypothesis fails at $k=1$, it will not directly jump to evaluate the noncausality at the 2nd moment and, therefore, the test for $k=2$ can be constructed. In this manner, the existence of causality in variance, and/or causality in mean can be tested.

The practical application of testing of causality by means of quantiles specifies three essential choices: (1) bandwidth, which is represented by $h,(2)$ kernel type for $K(\bullet)$ and $L(\bullet)$ as shown in Equations (6) and (9), and (3) the lag order, which is represented by p. The determination of lag order was done by employing Schwarz Information Criterion (SIC) underneath vector autoregression (VAR), including natural resources, globalization, and energy consumption. The least square cross-validation method was used for the selection of bandwidth values. Lastly, the Gaussian kernels were employed for computing the $K(\bullet)$ and $L(\bullet)$.

\section{Data Analysis and Interpretation}

The aim of this study was to investigate the dynamic causal effect of natural resources and globalization on utilization of energy in top Asian countries. In so doing, the recent study used natural resources' rent (\% of gross domestic product (GDP)) as a proxy of natural resources (NAR); overall globalization index, as represented by GLO (which consists of economic, social, and political globalization); and utilization of energy (EGY), which is a measure of per capita of $\mathrm{Kg}$ of oil equivalent for top Asian nations including China, India, Indonesia, Malaysia, and Thailand. The selection of these nations was made as they have the most natural resources among all the Asian nations. The data for NAR and EGY was gathered from the World Bank, however, the information for GLO was collected from the KOF Swiss Economic Institute. Yearly information was gathered for 1970-2018. As the aforementioned methodology needs long time-series information [71], hence, the recent study transformed the yearly information into quarterly information by selecting a quadratic match-sum technique. This technique is beneficial once lower frequency information is transformed into higher frequency information, as it corrects the seasonality problem and connects the end-to-end deviation in the sample period. This technique was also suggested in previous research $[72,73]$. Beginning with the fundamental test, the descriptive statistics are presented in Table 1.

The findings of the descriptive statistics confirmed that the mean (average) coefficients of NAR were positive for all top Asian countries. The biggest coefficient of mean for NAR was for Malaysia at 18.884 (ranged from 7.163 to 37.570) followed by Indonesia at 10.614 (ranged from 3.718 to 33.658). The smallest coefficient of mean of NAR was for Thailand at 1.725 (ranged from 0.562 to 3.785 ) followed 
by India at 2.985 (ranged from 0.834 to 7.351 ). China had the middle coefficient of mean for NAR at 6.202 (ranged from 0.811 to 19.232). On the other hand, the highest coefficient of mean for GLO was for Malaysia at 65.411 (varied from 47.769 to 79.615 ) followed by Thailand at 51.130 (varied from 32.576 to 69.129). The lowest coefficient of mean for GLO was for China at 46.262 (varied from 23.034 to 61.994) followed by India at 42.420 (varied from 31.081 to 58.274 ). In addition, the middle coefficient of mean for GLO was for Indonesia at 49.384 (varied from 32.022 to 63.315). Finally, the mean coefficients of EGY were also positive for all countries. The leading coefficient of mean was for Malaysia at 1637.991 (fluctuated from 523.576 to 3003.456) followed by China at 1013.589 (fluctuated from 464.933 to 2236.730). The lowest mean coefficient of EGY was for India at 390.043 (fluctuated from 267.309 to 636.570) followed by Indonesia at 584.885 (fluctuated from 297.306 to 883.918 ). The middle coefficient of mean of EGY was for Thailand at 979.875 (fluctuated from 360.594 to 1991.594).

Table 1. Results of descriptive statistics for top Asian economies.

\begin{tabular}{|c|c|c|c|c|c|c|c|c|}
\hline Countries & Mean & Min & Max & Std.Dev. & Skew & Kurtosis & JB test & $p$ Value \\
\hline \multicolumn{9}{|c|}{ Panel A: Natural Resources (\% of GDP) } \\
\hline China & 6.202 & 0.811 & 19.232 & 4.714 & 1.289 & 4.136 & 14.874 & 0.001 \\
\hline India & 2.985 & 0.834 & 7.351 & 1.199 & 0.933 & 5.478 & 18.039 & 0.000 \\
\hline Indonesia & 10.614 & 3.718 & 33.658 & 5.955 & 1.913 & 7.271 & 61.649 & 0.000 \\
\hline Malaysia & 18.844 & 7.163 & 37.570 & 8.737 & 0.436 & 3.907 & 13.664 & 0.001 \\
\hline Thailand & 1.725 & 0.562 & 3.785 & 0.833 & 0.454 & 2.235 & 22.644 & 0.000 \\
\hline \multicolumn{9}{|c|}{ Panel B: Globalization Index (including Political, Social, and Economic Globalization) } \\
\hline China & 42.262 & 23.034 & 61.994 & 14.348 & 0.097 & 3.366 & 15.074 & 0.000 \\
\hline India & 42.420 & 31.081 & 58.274 & 10.221 & 0.441 & 3.546 & 15.425 & 0.000 \\
\hline Indonesia & 49.384 & 32.022 & 63.315 & 9.994 & 0.033 & 3.447 & 14.532 & 0.001 \\
\hline Malaysia & 65.411 & 47.769 & 79.615 & 10.494 & -0.103 & 4.578 & 13.873 & 0.001 \\
\hline Thailand & 51.130 & 32.576 & 69.129 & 12.855 & 0.037 & 5.410 & 14.750 & 0.001 \\
\hline \multicolumn{9}{|c|}{ Panel C: Primary Energy Consumption (Per capita of Kg of Oil Equivalent) } \\
\hline China & 1013.589 & 464.933 & 2236.730 & 551.683 & 1.142 & 2.911 & 9.803 & 0.007 \\
\hline India & 390.043 & 267.309 & 636.570 & 108.122 & 0.812 & 2.606 & 15.236 & 0.000 \\
\hline Indonesia & 584.885 & 297.306 & 883.918 & 203.876 & -0.006 & 3.446 & 24.527 & 0.000 \\
\hline Malaysia & 1637.991 & 523.576 & 3003.456 & 810.742 & 0.175 & 4.610 & 23.851 & 0.000 \\
\hline Thailand & 979.875 & 360.594 & 1991.594 & 537.228 & 0.436 & 3.800 & 24.126 & 0.000 \\
\hline \multicolumn{9}{|c|}{ Source: Author Estimations } \\
\hline
\end{tabular}

Furthermore, the present study reported the skewness and kurtosis values, which were positive in almost all cases, however, the value of kurtosis was more than 3, which indicates a presence of nonlinearity in the dataset. In addition, the present research further applied the Jarque-Bera (JB) test to check the normality of the variables in all countries. The JB test statistics were statistically significant, which means NAR, GLO, and EGY were not normally distributed in all countries. The findings of the JB test also indicated a presence of nonlinearity among the variables for all countries. Hence, there is a need to apply a proper test to affirm the nonlinearity among the selected variables in the dataset [74]. In the current study, this was done by applying the BDS test for nonlinearity [75]. The findings of this test are reported in Table 2. The outcomes provide enough evidence to reject the null hypothesis of residual at different inserted dimensions $(\mathrm{m})$, for the entire set of cases measured. The outcomes provide enough evidence of nonlinear association among NAR, GLO, and EGY in all 
countries. Therefore, the methods that focus on linear assumptions cannot be considered reliable and robust. Those outcomes provide adequate evidence of nonlinear relationships in the dataset.

Table 2. Results of BDS test for nonlinearity.

\begin{tabular}{|c|c|c|c|c|c|c|c|c|c|c|}
\hline Country & $m=2$ & $p$-Value & $m=3$ & $p$-Value & $m=4$ & $p$-Value & $m=5$ & $p$-Value & $m=6$ & $p$-Value \\
\hline \multicolumn{11}{|c|}{ Natural Resources Rent Equation Residual } \\
\hline China & 37.315 & 0.000 & 41.507 & 0.000 & 45.242 & 0.000 & 50.024 & 0.000 & 55.590 & 0.000 \\
\hline India & 46.211 & 0.000 & 49.595 & 0.000 & 53.241 & 0.000 & 57.809 & 0.000 & 64.220 & 0.000 \\
\hline Indonesia & 36.192 & 0.000 & 41.791 & 0.000 & 45.884 & 0.000 & 51.871 & 0.000 & 58.125 & 0.000 \\
\hline Malaysia & 56.875 & 0.000 & 62.212 & 0.000 & 67.707 & 0.000 & 74.446 & 0.000 & 83.163 & 0.000 \\
\hline Thailand & 79.621 & 0.000 & 85.632 & 0.000 & 92.794 & 0.000 & 102.972 & 0.000 & 116.824 & 0.000 \\
\hline \multicolumn{11}{|c|}{ Globalization Equation Residual } \\
\hline China & 44.535 & 0.000 & 47.897 & 0.000 & 51.903 & 0.000 & 57.596 & 0.000 & 65.344 & 0.000 \\
\hline India & 31.812 & 0.000 & 34.797 & 0.000 & 37.871 & 0.000 & 41.640 & 0.000 & 46.516 & 0.000 \\
\hline Indonesia & 20.243 & 0.000 & 23.375 & 0.000 & 25.665 & 0.000 & 29.013 & 0.000 & 32.511 & 0.000 \\
\hline Malaysia & 25.847 & 0.000 & 27.740 & 0.000 & 29.780 & 0.000 & 32.335 & 0.000 & 35.921 & 0.000 \\
\hline Thailand & 20.872 & 0.000 & 23.216 & 0.000 & 25.305 & 0.000 & 27.980 & 0.000 & 31.093 & 0.000 \\
\hline \multicolumn{11}{|c|}{ Energy Consumption Equation Residual } \\
\hline China & 16.954 & 0.000 & 18.234 & 0.000 & 19.759 & 0.000 & 21.927 & 0.000 & 24.876 & 0.000 \\
\hline India & 12.111 & 0.000 & 13.247 & 0.000 & 14.417 & 0.000 & 15.852 & 0.000 & 17.709 & 0.000 \\
\hline Indonesia & 7.707 & 0.000 & 8.899 & 0.000 & 9.770 & 0.000 & 11.045 & 0.000 & 12.377 & 0.000 \\
\hline Malaysia & 9.840 & 0.000 & 10.561 & 0.000 & 11.337 & 0.000 & 12.310 & 0.000 & 13.675 & 0.000 \\
\hline Thailand & 7.946 & 0.000 & 8.838 & 0.000 & 9.634 & 0.000 & 10.652 & 0.000 & 11.837 & 0.000 \\
\hline
\end{tabular}

Source: Authors Estimation. Note: $m$ denotes the embedding dimension of the BDS test. $p$-value is the probability of obtaining results as extreme as the observed results of a statistical hypothesis test, assuming that the null hypothesis is correct.

In the next phase, the present study applied two novel unit root tests: augmented Dickey-Fuller (ADF) and Zivot and Andrew structural break unit root test. These tests were used to affirm the stationary features for NAR, GLO, and EGY in all countries. The findings of both unit root tests are displayed in Table 3. The results of unit root tests confirmed that NAR, GLO, and EGY all showed nonstationary behavior at level series and became stationary at the first different series. Put simply, the outcome confirmed that all variables had a unique order of integration at the first difference series. After the unique order of integration, the present research applied a nonlinear cointegration method called quantile cointegration [76]. This method was used to investigate the long-run nonlinear connection between NAR, GLO, and EGY. The findings are displayed in Table 4. The findings reported $\alpha$ and $\delta$ coefficient values for both NAR and GLO models with EGY in all selected top Asian countries. Moreover, the findings of quantile cointegration also reported the critical value at $1 \%, 5 \%$, and $10 \%$. The results confirmed that all the calculated values were greater than the critical values, suggesting a rejection of the null hypothesis. In general, the outcomes confirmed a long-run nonlinear relationship between NAR with EGY and GLO with EGY in all top Asian countries.

In the final phase, the present research applied nonparametric causality in quantiles [1]. The aim of this method was to examine the causal connection of NAR and GLO with the return and volatility of EGY across different quantile distributions. The findings are reported in Figure 1. Every graph represents return values (mean) and volatility (variance) along with the critical value of $5 \%$ and $10 \%$, respectively. Moreover, there are two axes in Figure 1, the horizontal axis ( $\mathrm{x}$-axis) explains the quantiles while the vertical axis (y-axis) describes the test results ( $\mathrm{t}$-stats value). The blue horizontal line symbolizes the $95 \%$ critical value of $t$-stats, whereas the orange dashed line exemplifies the $90 \%$ 
critical value of the test. The green dashed line explains the results for energy consumption returns and the yellow dark line describe the results for volatility.

Table 3. Results of unit root test.

\begin{tabular}{|c|c|c|c|c|c|c|}
\hline Variables & ADF (Level) & $\operatorname{ADF}(\Delta)$ & ZA (Level) & Break Year & $\mathrm{ZA}(\Delta)$ & Break Year \\
\hline \multicolumn{7}{|c|}{ Panel A: Natural Resources Rents } \\
\hline China & 0.184 & $-3.853^{* * *}$ & -1.075 & 2008 Q2 & $-11.594^{* * *}$ & 1996 Q2 \\
\hline India & -1.483 & $-4.549 * * *$ & -2.049 & 2010 Q1 & $-9.593^{* * *}$ & 2015 Q3 \\
\hline Indonesia & -2.044 & $-3.069^{* * *}$ & -1.531 & 1984 Q4 & $-7.591^{* * *}$ & 2008 Q1 \\
\hline Malaysia & -0.338 & $-5.124^{* * *}$ & -0.916 & 1999 Q2 & $-10.583^{* * *}$ & 2004 Q4 \\
\hline Thailand & -1.684 & $-4.616^{* * *}$ & -2.021 & 2012 Q3 & $-6.005^{* * *}$ & 2016 Q4 \\
\hline \multicolumn{7}{|c|}{ Panel B: Globalization } \\
\hline China & -0.472 & $-4.146^{* * *}$ & -2.473 & 2014 Q1 & $-6.483^{* * *}$ & $2001 \mathrm{Q} 2$ \\
\hline India & 1.271 & $-3.892^{* * *}$ & 0.583 & 2009 Q1 & $-4.584^{* * *}$ & 2006 Q2 \\
\hline Indonesia & 0.325 & $-4.093^{* * *}$ & -0.482 & $2001 \mathrm{Q} 2$ & $-6.482 * * *$ & 1995 Q3 \\
\hline Malaysia & -0.937 & $-5.483^{* * *}$ & -1.486 & 1997 Q4 & $-7.482 * * *$ & 1984 Q1 \\
\hline Thailand & -2.081 & $-3.918^{* * *}$ & -2.483 & 1988 Q4 & $-5.002 * * *$ & 2015 Q4 \\
\hline \multicolumn{7}{|c|}{ Panel C: Energy Consumption } \\
\hline China & -0.931 & $-5.382^{* * *}$ & -1.583 & 1976 Q4 & $-6.413^{* * *}$ & 2007 Q1 \\
\hline India & -2.081 & $-10.413^{* * *}$ & -2.321 & 1984 Q4 & $-11.275^{* * *}$ & 2007 Q2 \\
\hline Indonesia & -1.226 & $-6.147^{* * *}$ & -1.894 & 2000 Q3 & $-6.326^{* * *}$ & 2014 Q2 \\
\hline Malaysia & -0.269 & $-5.091^{* * *}$ & -0.943 & 2016 Q2 & $-5.961^{* * *}$ & 1992 Q1 \\
\hline Thailand & -0.852 & $-4.381^{* * *}$ & -1.035 & 2017 Q1 & $-5.039^{* * *}$ & 2011 Q3 \\
\hline
\end{tabular}

Note: The values in the table specify statistical values of the ADF and ZA tests. The asterisks ${ }^{* * *}, * *$ and ${ }^{*}$ represent level of significance at $1 \%, 5 \%$, and $10 \%$, respectively.

Table 4. Results of the quantile cointegration test.

\begin{tabular}{|c|c|c|c|c|c|}
\hline \multicolumn{6}{|c|}{ China } \\
\hline \multicolumn{6}{|c|}{ Modelling between Energy and Natural Resources } \\
\hline Model & Coefficient & Supremum Norm Value & Critical Value at $1 \%$ & Critical Value at $5 \%$ & Critical Value at $10 \%$ \\
\hline \multirow{2}{*}{$\mathrm{EGY}_{\mathrm{t}}$ vs. $\mathrm{NAR}_{\mathrm{t}}$} & $\alpha$ & 3503.962 & 1688.804 & 1260.819 & 442.479 \\
\hline & $\delta$ & 702.358 & 368.555 & 206.518 & 180.155 \\
\hline \multicolumn{6}{|c|}{ Modelling between Energy and Globalization } \\
\hline Model & Coefficient & Supremum Norm Value & Critical Value at $1 \%$ & Critical Value at $5 \%$ & Critical Value at $10 \%$ \\
\hline \multirow{2}{*}{$\mathrm{EGY}_{\mathrm{t}}$ vs. $\mathrm{GLO}_{\mathrm{t}}$} & $\alpha$ & 1209.021 & 582.712 & 435.038 & 152.675 \\
\hline & $\delta$ & 242.344 & 127.168 & 71.258 & 62.161 \\
\hline \multicolumn{6}{|c|}{ India } \\
\hline \multicolumn{6}{|c|}{ Modelling between Energy and Natural Resources } \\
\hline Model & Coefficient & Supremum Norm Value & Critical Value at $1 \%$ & Critical Value at $5 \%$ & Critical Value at $10 \%$ \\
\hline \multirow{2}{*}{$\mathrm{EGY}_{\mathrm{t}}$ vs. $\mathrm{NAR}_{\mathrm{t}}$} & $\alpha$ & 4736.817 & 1448.406 & 792.264 & 388.926 \\
\hline & $\delta$ & 1289.183 & 482.926 & 287.88 & 207.423 \\
\hline \multicolumn{6}{|c|}{ Modelling between Energy and Globalization } \\
\hline Model & Coefficient & Supremum Norm Value & Critical Value at $1 \%$ & Critical Value at $5 \%$ & Critical Value at $10 \%$ \\
\hline \multirow{2}{*}{$\mathrm{EGY}_{\mathrm{t}}$ vs. $\mathrm{GLO}_{\mathrm{t}}$} & $\alpha$ & 6444.329 & 1970.523 & 1077.857 & 529.124 \\
\hline & $\delta$ & 1753.904 & 657.009 & 391.654 & 282.195 \\
\hline
\end{tabular}


Table 4. Cont.

\begin{tabular}{|c|c|c|c|c|c|}
\hline \multicolumn{6}{|c|}{ Indonesia } \\
\hline \multicolumn{6}{|c|}{ Modelling between Energy and Natural Resources } \\
\hline Model & Coefficient & Supremum Norm Value & Critical Value at $1 \%$ & Critical Value at $5 \%$ & Critical Value at $10 \%$ \\
\hline $\mathrm{EGY}_{\mathrm{t}}$ vs. NAR $\mathrm{t}$ & $\delta$ & 1688.849 & 975.646 & 572.689 & 249.982 \\
\hline \multicolumn{6}{|c|}{ Modelling between Energy and Globalization } \\
\hline \multirow{2}{*}{$\mathrm{EGY}_{\mathrm{t}}$ vs. $\mathrm{GLO}_{\mathrm{t}}$} & $\alpha$ & 4641.523 & 3051.622 & 1864.071 & 1251.391 \\
\hline & $\delta$ & 2722.924 & 1573.03 & 923.344 & 403.046 \\
\hline \multicolumn{6}{|c|}{ Malaysia } \\
\hline \multicolumn{6}{|c|}{ Modelling between Energy and Natural Resources } \\
\hline \multicolumn{6}{|c|}{ Modelling between Energy and Globalization } \\
\hline Model & Coefficient & Supremum Norm Value & Critical Value at $1 \%$ & Critical Value at $5 \%$ & Critical Value at $10 \%$ \\
\hline \multirow{2}{*}{$\mathrm{EGY}_{\mathrm{t}}$ vs. $\mathrm{GLO}_{\mathrm{t}}$} & $\alpha$ & 2315.195 & 674.524 & 454.36 & 251.026 \\
\hline & $\delta$ & 1310.597 & 521.928 & 303.084 & 157.711 \\
\hline \multicolumn{6}{|c|}{ Thailand } \\
\hline \multicolumn{6}{|c|}{ Modelling between Energy and Natural Resources } \\
\hline Model & Coefficient & Supremum Norm Value & Critical Value at $1 \%$ & Critical Value at $5 \%$ & Critical Value at $10 \%$ \\
\hline
\end{tabular}

EGY From NAR

\section{(i) China}

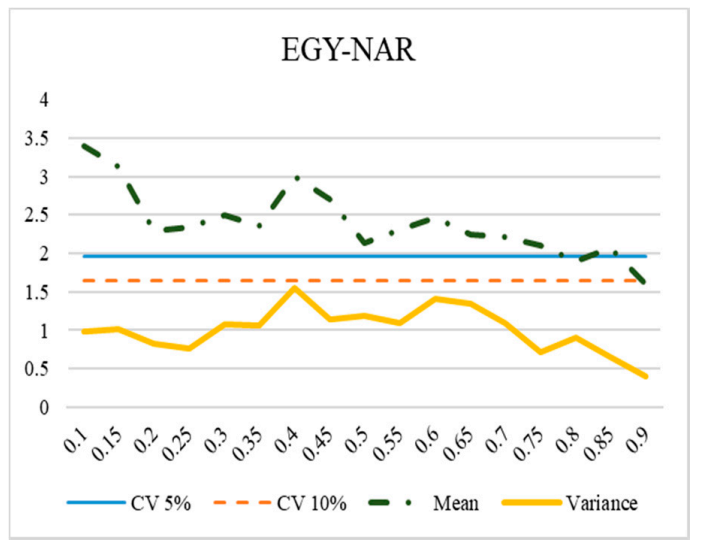

\section{EGY From GLO}

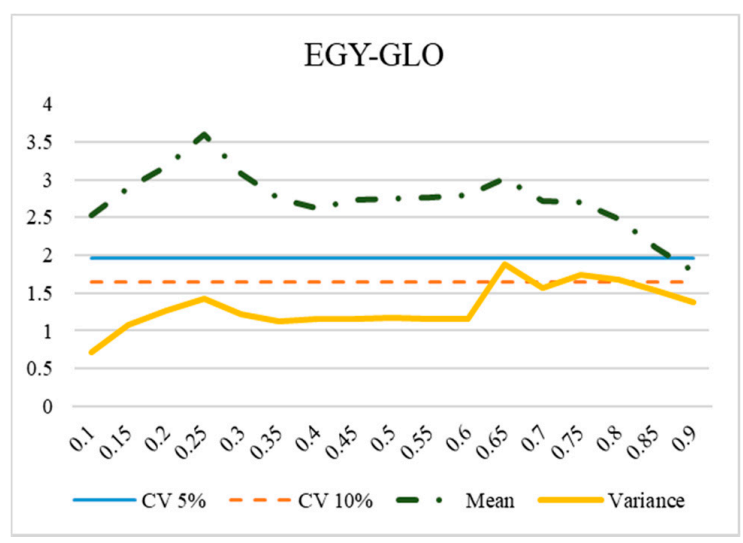

Figure 1. Cont. 


\section{(ii) India}

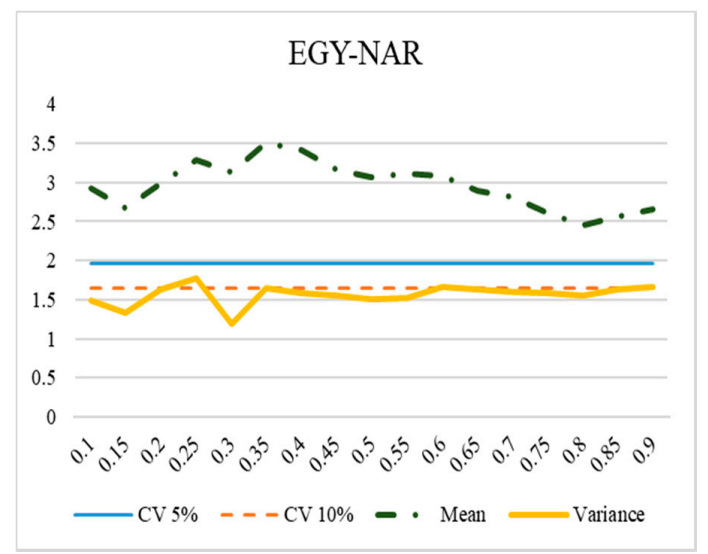

(iii) Indonesia

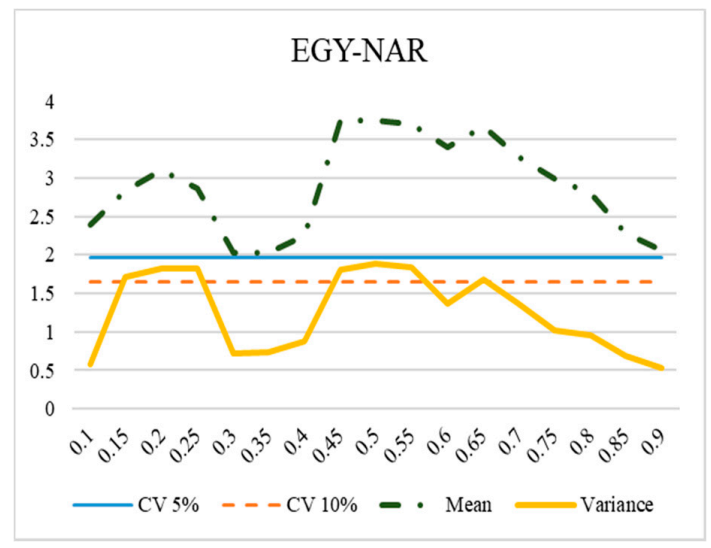

(iv) Malaysia

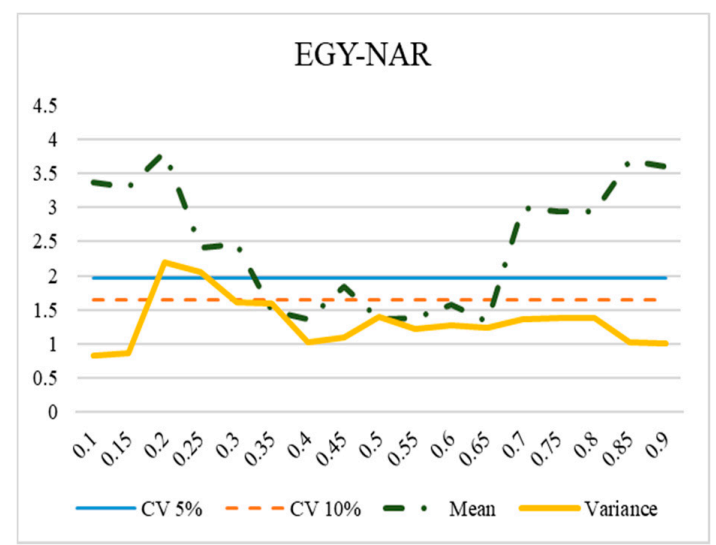

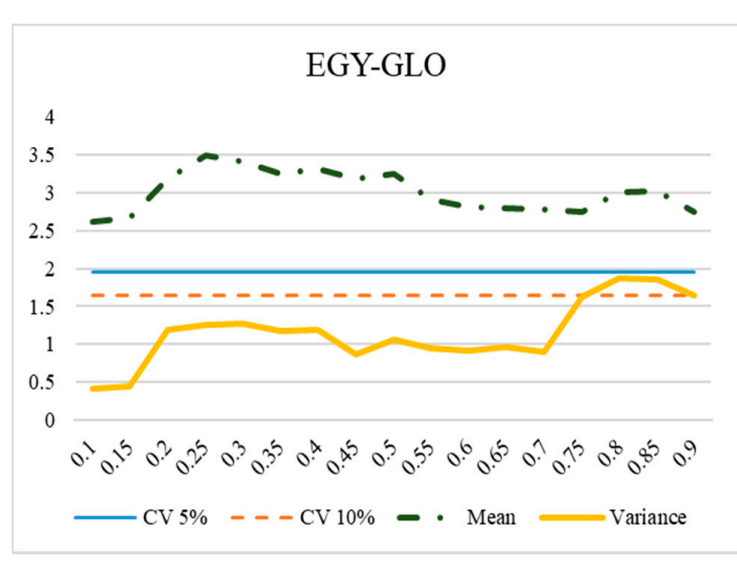
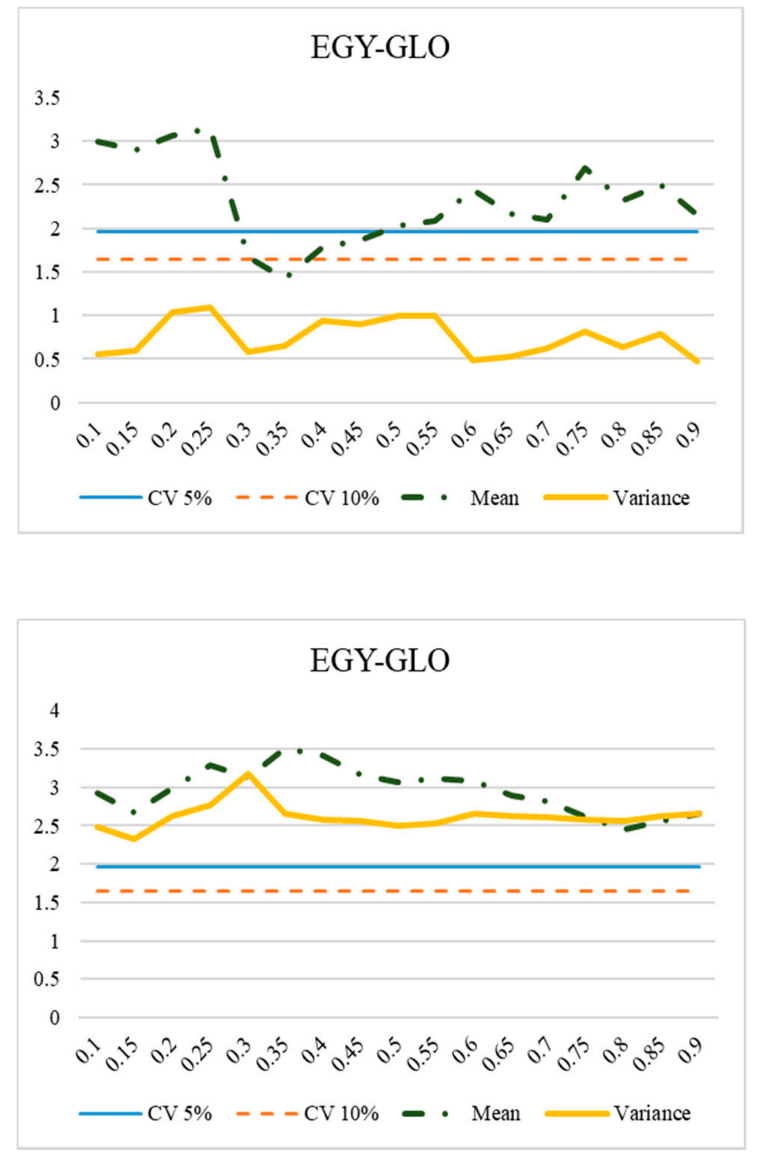

Figure 1. Cont. 
(v) Thailand
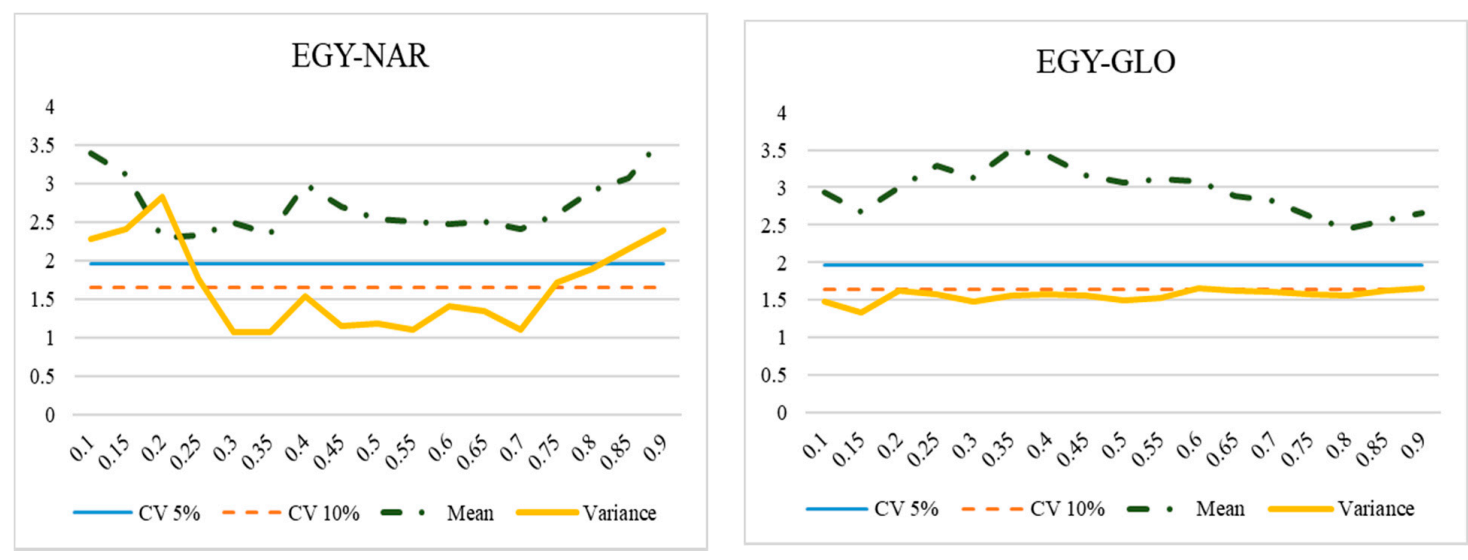

Figure 1. Results from nonparametric causality in quantiles.

In the case of China, the effect of NAR returns was significant for all lower, middle, and upper quantiles of the provisional distribution of EGY. The effect became strong and more significant in the lower quantiles with the t-stat value of approximately 3.4. The current study observed no causal effect of returns of NAR on the volatility of EGY in the case of the China. Moreover, the causal effect on volatility was not asymmetric, because they were insignificant for the upper, middle, and lower quantiles of the conditional distribution. On the other hand, the effect of GLO returns was also significant for all quantiles of distribution on the returns of EGY. The effect became more noteworthy in the low quantiles with the t-stats coefficient of approximately 3.56. However, the current research found no causal connection between returns of GLO and volatility of EGY. Put simply, the findings confirmed that returns of NAR and GLO had a significant causal impact on the returns of EGY at all quantiles.

In the situation of India, the impact of NAR returns was noteworthy for all quantiles of the returns of EGY. Moreover, the impact was strong and more significant at lower and middle quantiles of the returns of EGY. However, the present research did not find any causal effect of NAR returns on the volatility of EGY. In addition, the effect of returns of GLO was significant on the returns of EGY, however, the effect of the returns of GLO was significant on the volatility of EGY only at the upper quantiles at the $10 \%$ level of significance. In general, the returns of NAR and GLO had significant causal impact on the returns of EGY across all quantiles. The findings of causality from NAR and GLO to EGY are very interesting in the case of Indonesia. The findings confirmed that the returns of NAR had causal impact on the return and volatility of EGY at lower to middle quantiles. On the other hand, the influence of returns of GLO had a causal impact on the returns of EGY but there was no evidence of a causality from returns of GLO to volatility of EGY in Indonesia. In the case of Malaysia, the effect of NAR returns was substantial on the returns of EGY only at the extreme quantiles (i.e., lower and upper). However, the returns of NAR had a significant causal impact on the volatility of EGY on the lower middle quantiles. On the other hand, the effect of GLO returns had a significant causal impact on the returns and volatility of EGY. Put simply, the returns of NAR had a causal impact on EGY returns only, whereas the returns of GLO had a causal connection with EGY returns and volatility. In the case of Thailand, the returns of NAR were significant for all quantiles of returns of EGY. Moreover, the effect was strong and more prominent at both extreme quantiles (i.e., lower and higher). However, the study found no causal connection between the returns of NAR and volatility of EGY. On the other hand, the effect of GLO on EGY returns was significant across all quantiles of distribution. The effect was more powerful at the lower middle quantiles. In addition, the study found no causal impact of GLO returns on the volatility of EGY in Thailand. 


\section{Conclusions}

Natural resources enable direct foreign investment to a country, and that has a tendency to improve the standard of living of the locals [11,12], however, it also adversely affects the potential growth of the country in the long term [13], thus making the host country intensely dependent on the consumption and extraction of the natural resources; this is referred to as a resource curse [14-18].

Moreover, most researchers are in agreement with respect to the adverse association between economic development and natural resources of a country [19-21]. Researchers also suggest that by improving institutional quality, having a good incentive program to the personnel engaged in the respective activities [22], and strengthening the political stability [23], the country can counter the phenomenon of being trapping in a resource curse.

Keeping this in mind, the current research aimed to investigate the causal effect of natural resources and globalization on the returns and volatility of the utilization of energy in top Asian economies. The findings of nonparametric methods of causality in quantile confirmed that the returns of NAR and GLO had a significant causal effect on the returns of EGY in the selected sample. These results are consistent with the earlier studies of Shahbaz et al. [41] and Shahbaz et al. [42] that investigated the globalization-energy link and Bekun, et al. [68] and Kwakwa, et al. [33] that examined the natural resource-energy association. On the other hand, the present study found no causal connection from the returns of NAR and GLO to volatility of EGY in any of the studied Asian countries.

The results shed greater insights on the level of energy dependence in the process of globalization and the utilization of natural resources in Asian economies. Knowing the positive role of globalization and natural resources in the growth of prospering countries [77-79], the findings of the current study implied higher challenges for government practitioners and policy makers, given the worldwide emphasis on energy conservation. The study suggested the need of implementing adequate environmental reforms and eco-friendly business practices to support energy efficiency in the course of integrating industries and allocating investments in local and foreign businesses. Moreover, the change of energy mix from coal-based to renewables can also satisfy the inevitable need of energy in industries without disrupting environmental sustainability. The current research is limited to only top Asian countries. Moreover, the present research is also limited to bivariate analysis, therefore, future research could apply multivariate advanced econometrics such as nonlinear ARDL, quantile ARDL, and a multiple wavelet coherence approach.

Author Contributions: All authors contributed equally. All authors have read and agreed to the published version of the manuscript.

Funding: This research received no external funding.

Conflicts of Interest: The authors declare no conflict of interest.

\section{References}

1. Balcilar, M.; Bekiros, S.; Gupta, R. The role of news-based uncertainty indices in predicting oil markets: A hybrid nonparametric quantile causality method. Empir. Econ. 2017, 53, 879-889. [CrossRef]

2. Hassan, S.T.; Xia, E.; Khan, N.H.; Shah, S.M.A. Economic growth, natural resources, and ecological footprints: Evidence from Pakistan. Environ. Sci. Pollut. Res. 2019, 26, 2929-2938. [CrossRef] [PubMed]

3. Baltgailis, J. The issues of increasing the effectiveness of teaching comparative economics. Insights Reg. Dev. 2019, 1, 190-199. [CrossRef]

4. Vigliarolo, F. Economic phenomenology: Fundamentals, principles and definition. Insights Reg. Dev. 2020, 2 , 418-429. [CrossRef]

5. Zeibote, Z.; Volkova, T.; Todorov, K. The impact of globalization on regional development and competitiveness: Cases of selected regions. Insights Reg. Dev. 2019, 1, 33-47. [CrossRef]

6. Bhuiyan, M.A.; Jabeen, M.; Zaman, K.; Khan, A.; Ahmad, J.; Hishan, S.S. The impact of climate change and energy resources on biodiversity loss: Evidence from a panel of selected Asian countries. Renew. Energy 2018, 117, 324-340. [CrossRef] 
7. Wu, S.; Li, L.; Li, S. Natural resource abundance, natural resource-oriented industry dependence, and economic growth: Evidence from the provincial level in China. Resour. Conserv. Recycl. 2018, 139, 163-171. [CrossRef]

8. Yongping, S.; Chusheng, Y. Abundant natural resources and industry structure distortion: Influence mechanism and multi-dimensional measure. Soc. Sci. Nanjing 2012, 6, 1-8.

9. Garayev, A.I.O.; Tanriverdiev, S.M.O.; Hajiyev, N.Q.-O. Analysis of the oil, price and currency factor of economic growth in Azerbaijan. Entrep. Sustain. Issues 2019, 6, 1335-1353.

10. Ustiuzhanin, A.A.; Liman, I.A.; Kiselitsa, E.P.; Shilova, N.N.; Leyman, T.I. The ruble exchange rate and the price of oil: Assessment of the degree of dependence, its causes and ways of overcoming. Entrep. Sustain. Issues 2019, 7, 121-132. [CrossRef]

11. Shahabadi, A.; Feyzi, S. The relationship between natural resources abundance, foreign direct investment and environmental performance in selected oil and developed countries during 1996-2013. Int. J. Resist. Econ. 2016, 4, 101-116.

12. Mikita, M.; Kolcun, M.; Spes, M.; Vojtek, M.; Ivancak, M. Impact of electrical power load time management at sizing and cost of hybrid renewable power system. Pol. J. Manag. Stud. 2017, 15, 154-162. [CrossRef]

13. Wang, K.; Wu, M.; Sun, Y.; Shi, X.; Sun, A.; Zhang, P. Resource abundance, industrial structure, and regional carbon emissions efficiency in China. Resour. Policy 2019, 60, 203-214. [CrossRef]

14. Song, M.; Wang, J.; Zhao, J. Coal endowment, resource curse, and high coal-consuming industries location: Analysis based on large-scale data. Resour. Conserv. Recycl. 2018, 129, 333-344. [CrossRef]

15. Gerelmaa, L.; Kotani, K. Further investigation of natural resources and economic growth: Do natural resources depress economic growth? Resour. Policy 2016, 50, 312-321. [CrossRef]

16. Badeeb, R.A.; Lean, H.H.; Clark, J. The evolution of the natural resource curse thesis: A critical literature survey. Resour. Policy 2017, 51, 123-134. [CrossRef]

17. Ahmed, K.; Mahalik, M.K.; Shahbaz, M. Dynamics between economic growth, labor, capital and natural resource abundance in Iran: An application of the combined cointegration approach. Resour. Policy 2016, 49, 213-221. [CrossRef]

18. Tyo, A.; Jazykbayeva, B.; Ten, T.; Kogay, G.; Spanova, B. Development tendencies of heat and energy resources: Evidence of Kazakhstan. Entrep. Sustain 2019, 7, 1514-1524. [CrossRef]

19. Sala-i-Martin, X.; Doppelhofer, G.; Miller, R.I. Determinants of long-term growth: A Bayesian averaging of classical estimates (BACE) approach. Am. Econ. Rev. 2004, 94, 813-835. [CrossRef]

20. Sala-i-Martin, X.X. I Just Ran Four Million Regressions; National Bureau of Economic Research: Cambridge, MA, USA, 1997.

21. Sachs, J.D.; Warner, A.M. Natural Resource Abundance and Economic Growth; National Bureau of Economic Research: Cambridge, MA, USA, 1995.

22. Robinson, J.A.; Torvik, R.; Verdier, T. Political foundations of the resource curse. J. Dev. Econ. 2006, 79, 447-468. [CrossRef]

23. Van Alstine, J.; Neumayer, E. The environmental Kuznets curve. Handb. Trade Environ. 2010, 2, 49-59.

24. Latif, Z.; Latif, S.; Ximei, L.; Pathan, Z.H.; Salam, S.; Jianqiu, Z. The dynamics of ICT, foreign direct investment, globalization and economic growth: Panel estimation robust to heterogeneity and cross-sectional dependence. Telemat. Inform. 2018, 35, 318-328. [CrossRef]

25. Luo, Y.; Bu, J. How valuable is information and communication technology? A study of emerging economy enterprises. J. World Bus. 2016, 51, 200-211. [CrossRef]

26. Widiyanti, M.; Sadalia, I.; Irawati, N.; Hendrawaty, E. Determining firm's performance: Moderating role of CSR in renewable energy sector of Indonesia. Pol. J. Manag. Stud. 2019, 19, 432-441.

27. Rahman, S.M.; Miah, M.D. The impact of sources of energy production on globalization: Evidence from panel data analysis. Renew. Sustain. Energy Rev. 2017, 74, 110-115. [CrossRef]

28. Miao, C.; Sadalia, I.; Irawati, N.; Hendrawaty, E. Natural resources utilization efficiency under the influence of green technological innovation. Resour. Conserv. Recycl. 2017, 126, 153-161. [CrossRef]

29. Asumadu-Sarkodie, S.; Owusu, P.A. Carbon dioxide emissions, GDP, energy use, and population growth: A multivariate and causality analysis for Ghana, 1971-2013. Environ. Sci. Pollut. Res. 2016, 23, 13508-13520. [CrossRef]

30. Hilson, G. The environmental impact of small-scale gold mining in Ghana: Identifying problems and possible solutions. Geogr. J. 2002, 168, 57-72. [CrossRef] 
31. Nasirudeen, A.; Allan, A. Managing the impacts of mining on Ghana's water resources from a legal perspective. J. Energy Nat. Resour. Manag. (JENRM) 2014, 1, 156-165.

32. Kwakwa, P.A. On the determinants of electricity power losses: Empirics from Ghana. OPEC Energy Rev. 2018, 42, 3-21. [CrossRef]

33. Kwakwa, P.A.; Alhassan, H.; Adu, G. Effect of natural resources extraction on energy consumption and carbon dioxide emission in Ghana. Int. J. Energy Sect. Manag. 2019, 14, 20-39. [CrossRef]

34. Shakhovskaya, L.; Petrenko, E.; Dzhindzholia, A.; Timonina, V. Market peculiarities of natural gass: Case of the Pacific Region. Entrep. Sustain. Issues 2018, 5, 555-564. [CrossRef]

35. Tvaronavičienè, M.; Baublys, J.; Raudeliūnienė, J.; Jatautaitè, D. Global energy consumption peculiarities and energy sources: Role of renewables. In Energy Transformation Towards Sustainability; Elsevier: Amsterdam, The Netherlands, 2020; pp. 1-49.

36. Fang, Y. Economic welfare impacts from renewable energy consumption: The China experience. Renew. Sustain. Energy Rev. 2011, 15, 5120-5128. [CrossRef]

37. Chetthamrongchai, P.; Jermsittiparsert, K.; Saengchai, S. How the nexus among the free trade, institutional quality and economic growth ffect the trade from ASEAN countries. Entrep. Sustain. Issues 2020, 7, 2079-2094. [CrossRef]

38. Narayan, P.K.; Narayan, S. Does environmental quality influence health expenditures? Empirical evidence from a panel of selected OECD countries. Ecol. Econ. 2008, 65, 367-374. [CrossRef]

39. Haseeb, M.; Kot, S.; Hussain, H.I.; Jermsittiparsert, K. Impact of economic growth, environmental pollution, and energy consumption on health expenditure and R\&D expenditure of ASEAN countries. Energies 2019, 12, 3598.

40. Shahbaz, M.; Shahzad, S.J.H.; Mahalik, M.K.; Sadorsky, P. How strong is the causal relationship between globalization and energy consumption in developed economies? A country-specific time-series and panel analysis. Appl. Econ. 2018, 50, 1479-1494. [CrossRef]

41. Shahbaz, M.; Lahiani, A.; Abosedra, S.; Hammoudeh, S. The role of globalization in energy consumption: A quantile cointegrating regression approach. Energy Econ. 2018, 71, 161-170. [CrossRef]

42. Shahbaz, M.; Mallick, H.; Mahalik, M.K.; Sadorsky, P. The role of globalization on the recent evolution of energy demand in India: Implications for sustainable development. Energy Econ. 2016, 55, 52-68. [CrossRef]

43. Cole, M.A. Does trade liberalization increase national energy use? Econ. Lett. 2006, 92, 108-112. [CrossRef]

44. Dreher, A. Does globalization affect growth? Evidence from a new index of globalization. Appl. Econ. 2006, 38, 1091-1110. [CrossRef]

45. Antweiler, W.; Copeland, B.R.; Taylor, M.S. Is free trade good for the environment? Am. Econ. Rev. 2001, 91, 877-908. [CrossRef]

46. McAusland, C. Globalisation's direct and indirect effects on the environment. Glob. Transp. Environ. 2010, 31, 31-53.

47. Zaidi, S.A.H.; Zafar, M.W.; Shahbaz, M.; Hou, F. Dynamic linkages between globalization, financial development and carbon emissions: Evidence from Asia Pacific Economic Cooperation countries. J. Clean. Prod. 2019, 228, 533-543. [CrossRef]

48. Coxhead, I. A new resource curse? Impacts of China's boom on comparative advantage and resource dependence in Southeast Asia. World Dev. 2007, 35, 1099-1119. [CrossRef]

49. Ross, M.L. The political economy of the resource curse. World Politics 1999, 51, 297-322. [CrossRef]

50. Yanıkkaya, H.; Turan, T. Curse or Blessing? An Empirical Re-examination of Natural Resource-Growth Nexus. J. Int. Dev. 2018, 30, 1455-1473. [CrossRef]

51. Sharif, A.; Afshan, S.; Qureshi, M.A. Idolization and ramification between globalization and ecological footprints: Evidence from quantile-on-quantile approach. Environ. Sci. Pollut. Res. 2019, 26, 11191-11211. [CrossRef]

52. Holmberg, K.; Kivikytö-Reponen, P.; Härkisaari, P.; Valtonen, K.; Erdemir, A. Global energy consumption due to friction and wear in the mining industry. Tribol. Int. 2017, 115, 116-139. [CrossRef]

53. Apergis, N.; Payne, J.E.; Menyah, K.; Wolde-Rufael, Y. On the causal dynamics between emissions, nuclear energy, renewable energy, and economic growth. Ecol. Econ. 2010, 69, 2255-2260. [CrossRef]

54. Speirs, J.; McGlade, C.; Slade, R. Uncertainty in the availability of natural resources: Fossil fuels, critical metals and biomass. Energy Policy 2015, 87, 654-664. [CrossRef] 
55. Saurin, J. Global environmental degradation, modernity and environmental knowledge. Environ. Politics 1993, 2, 46-64. [CrossRef]

56. Bilgili, F.; Koçak, E.; Bulut, Ü. The dynamic impact of renewable energy consumption on CO2 emissions: A revisited Environmental Kuznets Curve approach. Renew. Sustain. Energy Rev. 2016, 54, 838-845. [CrossRef]

57. Begum, R.A.; Sohag, K.; Abdullah, S.M.S.; Jaafar, M. $\mathrm{CO}_{2}$ emissions, energy consumption, economic and population growth in Malaysia. Renew. Sustain. Energy Rev. 2015, 41, 594-601. [CrossRef]

58. Nasreen, S.; Anwar, S.; Ozturk, I. Financial stability, energy consumption and environmental quality: Evidence from South Asian economies. Renew. Sustain. Energy Rev. 2017, 67, 1105-1122. [CrossRef]

59. Pérez-Lombard, L.; Ortiz, J.; Pout, C. A review on buildings energy consumption information. Energy Build. 2008, 40, 394-398. [CrossRef]

60. Azam, M.; Khan, A.Q.; Zafeiriou, E.; Arabatzis, G. Socio-economic determinants of energy consumption: An empirical survey for Greece. Renew. Sustain. Energy Rev. 2016, 57, 1556-1567. [CrossRef]

61. Bhattacharjee, S.; Reichard, G. Socio-economic factors affecting individual household energy consumption: A systematic review. In Proceedings of the ASME 2011 5th International Conference on Energy Sustainability, Washington, DC, USA, 7-10 August 2011.

62. Keho, Y. What drives energy consumption in developing countries? The experience of selected African countries. Energy Policy 2016, 91, 233-246. [CrossRef]

63. Azam, M.; Khan, A.Q.; Zaman, K.; Ahmad, M. Factors determining energy consumption: Evidence from Indonesia, Malaysia and Thailand. Renew. Sustain. Energy Rev. 2015, 42, 1123-1131. [CrossRef]

64. Murshed, M.; Tul Jannat, F.; Amin, S. An Empirical Investigation of globalization and energy consumption: Evidence from Bangladesh. World J. Soc. Sci. 2018, 8, 54-68.

65. Shahbaz, M.; Solarin, S.A.; Sbia, R.; Bibi, S. Does energy intensity contribute to $\mathrm{CO}_{2}$ emissions? A trivariate analysis in selected African countries. Ecol. Indic. 2015, 50, 215-224. [CrossRef]

66. Koengkan, M.; Poveda, Y.E.; Fuinhas, J.A. Globalisation as a motor of renewable energy development in Latin America countries. GeoJournal 2019, 1-12. [CrossRef]

67. Shahbaz, M.; Mahalik, M.K.; Shahzad, S.J.H.; Hammoudeh, S. Does the environmental K uznets curve exist between globalization and energy consumption? G lobal evidence from the cross-correlation method. Int. J. Financ. Econ. 2019, 24, 540-557. [CrossRef]

68. Bekun, F.V.; Alola, A.A.; Sarkodie, S.A. Toward a sustainable environment: Nexus between $\mathrm{CO}_{2}$ emissions, resource rent, renewable and nonrenewable energy in 16-EU countries. Sci. Total Environ. 2019, 657, 1023-1029. [CrossRef] [PubMed]

69. Jeong, K.; Härdle, W.K.; Song, S. A consistent nonparametric test for causality in quantile. Econom. Theory 2012, 28, 861-887. [CrossRef]

70. Nishiyama, Y.; Hitomi, K.; Kawasaki, Y.; Jeong, K. A consistent nonparametric test for nonlinear causality-Specification in time series regression. J. Econom. 2011, 165, 112-127. [CrossRef]

71. Hussain, H.I.; Slusarczyk, B.; Kamarudin, F.; Thaker, H.M.T.; Szczepańska-Woszczyna, K. An investigation of an adaptive neuro-fuzzy inference system to predict the relationship among energy intensity, globalization, and financial development in major ASEAN economies. Energies 2020, 13, 850. [CrossRef]

72. Arain, H.; Han, L.; Sharif, A.; Meo, M.S. Investigating the effect of inbound tourism on FDI: The importance of quantile estimations. Tour. Econ. 2019. [CrossRef]

73. Shahzad, S.J.H.; Shahbaz, M.; Ferrer, R.; Kumar, R.R. Tourism-led growth hypothesis in the top ten tourist destinations: New evidence using the quantile-on-quantile approach. Tour. Manag. 2017, 60, $223-232$. [CrossRef]

74. Mishra, S.; Sharif, A.; Khuntia, S.; Meo, S.A.; Khan, S.A.R. Does oil prices impede Islamic stock indices? Fresh insights from wavelet-based quantile-on-quantile approach. Resour. Policy 2019, 62, 292-304. [CrossRef]

75. Broock, W.A.; Scheinkman, J.A.; Dechert, W.D.; LeBaron, B. A test for independence based on the correlation dimension. Econom. Rev. 1996, 15, 197-235. [CrossRef]

76. Xiao, Z. Functional-coefficient cointegration models. J. Econom. 2009, 152, 81-92. [CrossRef]

77. Nawaz, K.; Lahiani, A.; Roubaud, D. Natural resources as blessings and finance-growth nexus: A bootstrap ARDL approach in an emerging economy. Resour. Policy 2019, 60, 277-287. [CrossRef] 
78. Hassan, S.T.; Xia, E.; Huang, J.; Khan, N.H.; Iqbal, K. Natural resources, globalization, and economic growth: Evidence from Pakistan. Environ. Sci. Pollut. Res. 2019, 26, 15527-15534. [CrossRef] [PubMed]

79. Kandil, M.; Shahbaz, M.; Mahalik, M.K.; Nguyen, D.K. The drivers of economic growth in China and India: Globalization or financial development? Int. J. Dev. Issues 2017, 16, 54-81. [CrossRef]

(C) 2020 by the authors. Licensee MDPI, Basel, Switzerland. This article is an open access article distributed under the terms and conditions of the Creative Commons Attribution (CC BY) license (http://creativecommons.org/licenses/by/4.0/). 